\title{
Combination of Organic Fertilizer, Anorganic Fertilizer and Bio-Fertilizer in Maize Cultivation in Dry Land, Banten
}

\author{
Pepi Nur Susilawati ${ }^{*}$ and Resmayeti Purba \\ Banten Assessment Institute for Agricultural Technology Indonesian Ministry of Agriculture, Ciruas \\ Serang, Banten 42182, Indonesia
}

\begin{abstract}
The research aims to study the response of the combination of organic fertilizers, inorganic fertilizers and bio-fertilizers to the growth and yield of Lamuru composite maize in the dry land of Kadumadang Village, Cimanuk, Pandeglang Regency, Banten. The treatments consisted of : A) 3 $\mathrm{t} /$ ha manure + urea $350 \mathrm{~kg}+100 \%$ fertilizer recommendation for Maize; B) Manure 3 tons / ha $+75 \%$ fertilizer recommendation for Maize; C) Manure $3 \mathrm{t} / \mathrm{ha}+50 \%$ fertilizer recommendation for Maize and D) Organic fertilizer $+25 \%$ fertilizer recommendation for Maize. Biosilica application was carried out on the 14, 28, 42, and 56 days after planting (DAS) with a dose of 40 liters/ha. The results showed that the treatment of $\mathrm{C}$ that the combination of of fertilizer 3 tonnes/ha of manure + recommendation of $50 \%$ fertilizer recommendation for Maize and Biosilica gave the best growth and yield of corn, with shelled production dry corn of $6.2 \mathrm{t} /$ ha (moisture content $17-18 \%$ ). This result is $16 \%$ higher when compared to the productivity of Pandeglang Regency in 2019 which reached $5.3 \mathrm{t} / \mathrm{ha}$.
\end{abstract}

\section{Introduction}

Corn is one of the main secondary crops in Indonesia with a relatively wide range of uses, especially for human consumption and animal feed needs. The development of corn cultivation in Banten today and in the future will be more directed at dry land that has low productivity. The potential of dry land scattered on Perhutani land is wide enough to be used for corn cultivation. Corn cultivation in Banten is mostly done by farmers if there is a program that involves farmer groups, while only a small part of it is self-supporting. The influencing factors and problems of maize farming in dry land and paddy fields can be seen from the economic and social and technical aspects of cultivation[1]. Farmers are less interested in planting corn because the market for shelled corn is uncertain. From the technical aspect of corn cultivation in a dry land, farmers have not provided balanced fertilizers, while the limiting factor for dry land is low organic matter content. Agricultural business in dry land is faced with several limiting factors, namely acid soil reaction, high $\mathrm{Al}$ and $\mathrm{Mn}$ content, high $\mathrm{P}$ fixation, nutrient deficiency $\mathrm{N}, \mathrm{P}, \mathrm{K}, \mathrm{Ca}, \mathrm{Mg}$ and $\mathrm{Mo}$, low cation

\footnotetext{
*Corresponding author: pepinurs@gmail.com
} 
exchange capacity (CEC), and stability low aggregate[2]. Composting on dry land can improve soil physical properties and corn plant growth[3,4]. Organic and inorganic fertilizers can be used to provide nutrients for plants, besides that organic fertilizers can improve the physical and chemical properties of the soil [5].

Balanced nutrients of nitrogen $(\mathrm{N})$, phosphorus $(\mathrm{P})$, and $\mathrm{K}$ (potassium) are needed for the optimal growth of corn plants. Deficiency of these nutrients often occurs in the soil so that it requires additional fertilizers, both organic fertilizers and inorganic fertilizers. Corn plants need N., especially for vegetative growth, photosynthesis, and protein formation. The application of $\mathrm{N}$ fertilizer increased cob size, seed weight, harvest index, and yield. Elemental $\mathrm{P}$ is needed to store and transfer energy from photosynthesis in the process of growth and production. $\mathrm{P}$ fertilization increases root volume, so it can absorb nutrients better and accelerate the ripening of seeds in corn. Potassium plays a role in forming carbohydrates and fat content, regulating the opening and closing of the stoma so that plants are more resistant to drought, more resistant to pests and diseases, and not easy to fall. The provision of sufficient and balanced $\mathrm{N}, \mathrm{P}$, and $\mathrm{K}$ fertilizers is a key factor in increasing maize yields[6,7]. One way to increase corn yields in dry land is the use of organic fertilizers and inorganic fertilizers combined with biological fertilizers is a dry land management strategy that can increase soil productivity, crop yields. High yields in a sustainable manner can be achieved if NPK fertilization is combined with the use of organic matter [8].

Biological fertilizers or bio fertilizers are fertilizers that contain live microorganisms which when applied to seeds (seed treatment), plant surfaces, or soil (application by spraying) will encourage plant growth by increasing the supply of key nutrients for plants. The declining level of soil fertility due to excessive and continuous use of inorganic fertilizers is a problem that must be addressed immediately. The efficiency of inorganic fertilization is needed as an effort to increase farming efficiency and the use of biological fertilizers on corn can increase yields Moelyohadi et al.[9].

There are quite a lot of biological fertilizers currently circulating in the market and have been used for the cultivation of food crops. The use of biological fertilizers can reduce the use of inorganic fertilizers in maize cultivation. In this experiment, the bio fertilizer used was Biosinta. Biosinta is produced by Indonesian Agricultural Postharvest Research and Development (ICAPOSTRD), which is a natural silica product made from rice husks, which can naturally strengthen plant resistance and maintain plant health from pests and diseases and drought attacks to increase production, leaving no harmful residues on crop yields. Biosinta can be applied to various phases of plant growth at a dose of 40 1/ha [10].

The problem of agriculture in dry land is degradation which results in a decrease in soil fertility [11]. The application of organic fertilizer can function as an ameliorant that can improve the physical, chemical and biological properties of the soil, which in turn will have an impact on increasing crop production $[12,13]$. The application of organic fertilizers also affects the availability of nutrients in the soil, so that the use of inorganic fertilizers can be reduced. Several studies have shown that organic and inorganic fertilization simultaneously can increase the growth and yield of maize [14]. This study aims to study the effect of organic and inorganic fertilizer application on corn production in dry land.

\section{Research Methodology}

The research was conducted in the Kadumadang Village, Mandalawangi district, Pandeglang Regency, Banten Province from December 2019 to February 2020. The location selection is based on the condition of the land which is dry land that is less fertile.. Corn cultivation was carried out on farmers' land and involved farmers in the implementation of the experiment 
The study used a Randomized Block Design (RAK) with 8 replications. The treatments studied were as follows:

$\mathrm{A}=$ Manure $3 \mathrm{t} / \mathrm{ha}+100 \%$ composite corn fertilizer recommendation: Urea $350 \mathrm{~kg}+100$

$\mathrm{kg} \mathrm{SP}-36+\mathrm{KCl} 50 \mathrm{~kg} / \mathrm{ha}$

$\mathrm{B}=$ Manure 3 tons $/$ ha $+75 \%$ composite corn fertilizer recommendation: Urea $262.5 \mathrm{~kg}+$

$75 \mathrm{~kg} \mathrm{SP}-36+\mathrm{KCl} 37.5 \mathrm{~kg} / \mathrm{ha}+$ Biosinta

$\mathrm{C}=$ Manure $3 \mathrm{t} / \mathrm{ha}+50 \%$ fertilizer recommendation for composite corn: Urea $175 \mathrm{~kg}+50$

$\mathrm{kg}+\mathrm{SP}-36+\mathrm{KCl} 25 \mathrm{~kg} / \mathrm{ha}+$ Biosinta

$\mathrm{D}=$ Manure $3 \mathrm{t} / \mathrm{ha}+25 \%$ fertilizer recommendation for corn composite Urea $87.5 \mathrm{~kg}+25$

$\mathrm{kg} \mathrm{SP}-36+$ Biosinta

The study used a plot with a size of $4 \times 5 \mathrm{~m}$. Channels between treatment plots were made with a width and depth of $10 \mathrm{~cm}$ so that there was no fertilizer contamination or surface water flow between one treatment plot and another and the distance between replicates was about $60 \mathrm{~cm}$. Lamuru composite corn was planted with a spacing of $75 \times 25$ $\mathrm{cm}, 1 \mathrm{plant} /$ hole so that the plant population in each treatment plot was 106 plants. Manure is given by mixing it with the soil at the time of tillage and is also used as a cover for planting corn seeds. In the first fertilization, half Urea fertilizer and all SP-36 and $\mathrm{KCl}$ fertilizers were applied when the corn plants were 10 days old, and the second fertilizer was applied when the corn plants were 30 days after planting, singly at a distance of about 10 $\mathrm{cm}$ from the planting hole. Bioriz is applied as a seed treatment, by mixing it with corn seeds at a dose of 200 grams $/ 15 \mathrm{~kg}$ of seeds. During land maintenance, maize plants were sprayed with Biosinta, which was carried out on days 14, 28, 42, and 56 at a dose of 40 liters/ha. The hoarding of corn plants was carried out at the age of 30 days. Weeding, irrigation, and eradication of plant pest organisms (OPT) are carried out as needed.

Parameters of plant growth and yield observed were plant height, the weight of biomass, harvest index, and yield of dry shelled corn. Plant height was observed at the time of harvest by measuring the plant height from the soil surface to the tip of the leaf. The weight of plant biomass was observed for each treatment and then dried in an oven at $70 \mathrm{oC}$ for 48 hours until constant dryness. Corn yields were weighed in the form of dry shells with a moisture content of $14 \%$, weighed from the net plot (after deducting one row of plants around the plot) for each treatment.

\section{Results and Discussion}

\subsection{Agronomic Performance of Maize Plants}

Analysis of variance in maize plant height at harvest showed that treatment had no significant effect on plant height but treatment $\mathrm{C}$ gave a higher plant height, namely an average of $191.3 \mathrm{~cm}$, followed by treatment B $(189.2 \mathrm{~cm})$, treatment D $(188 \mathrm{~cm}) .0 .0 \mathrm{~cm})$, treatment A $(186.5 \mathrm{~cm})$. This is in line with the results of Purwani and Nurjaya's research, where the application of biological fertilizers and inorganic fertilizers at a dose of $50 \%$ gave the best results on maize biomass [15].

Analysis of variance showed that the application of biosynta bio fertilizer had a significant effect on the length of the cob and the number of rows/cobs. Without the application of bio fertilizers, the length of the cob was 14.5 and the number of rows/cob was 12 , while the treatment with bio fertilizers showed that the length of the cobs ranged from 15.2-18.3 cm while the number of rows/cob ranged from 14-16. The highest cob length and number of rows/cobs were obtained in the treatment of manure $3 \mathrm{t} / \mathrm{ha}+50 \%$ composite corn fertilizer recommendation: Urea $175 \mathrm{~kg}+50 \mathrm{~kg}+\mathrm{SP}-36+\mathrm{KCl} 25 \mathrm{~kg} / \mathrm{ha}+$ Biosinta, 16 and $18.3 \mathrm{~cm}$. The results of other studies showed that composting with the 
application of biological fertilizers (K-PH) was the best treatment because it could increase the length of the cob [16].

Table 1. Components of maize cultivation yield in Mandalawangi district, Pandeglang Regency Banten Province

\begin{tabular}{|l|c|c|c|c|}
\hline Treatment & $\begin{array}{c}\text { Plant Height } \\
\text { (cm) }\end{array}$ & $\begin{array}{c}\text { Cob Length } \\
(\mathbf{c m})\end{array}$ & $\begin{array}{c}\text { Number of } \\
\text { rows/cob }\end{array}$ & $\begin{array}{c}\text { Seed weight of 100 } \\
\text { number (gr) }\end{array}$ \\
\hline A & $186.5 \mathrm{a}$ & $14.5 \mathrm{c}$ & $12 \mathrm{a}$ & $27.10 \mathrm{a}$ \\
\hline $\mathrm{B}$ & $189.2 \mathrm{a}$ & $15.2 \mathrm{~b}$ & $14 \mathrm{a}$ & $28.10 \mathrm{~b}$ \\
\hline $\mathrm{C}$ & $191.3 \mathrm{a}$ & $18.3 \mathrm{a}$ & $16 \mathrm{a}$ & $31.60 \mathrm{~b}$ \\
\hline $\mathrm{D}$ & $188.0 \mathrm{a}$ & $16.6 \mathrm{~b}$ & $14 \mathrm{a}$ & $30.30 \mathrm{~b}$ \\
\hline
\end{tabular}

Analysis of variance observed in the weight of 100 seeds at a moisture content of 17$18 \%$ (Table 1) showed that the application of biosynta biological fertilizer had a significant effect on the weight of 100 seeds. Without fertilizer application, the weight of 100 seeds was $27.1 \mathrm{~g}$, while for the biological fertilizer treatment; the weight of 100 seeds was between 28.1-31.6 g. The highest weight of 100 seeds was obtained in the treatment of manure $3 \mathrm{t} / \mathrm{ha}+50 \%$ fertilizer recommendation for composite corn: Urea $175 \mathrm{~kg}+50 \mathrm{~kg}+$ $\mathrm{SP}-36+\mathrm{KCl} 25 \mathrm{~kg} / \mathrm{ha}+$ Biosinta while the lowest weight of 100 seeds was obtained in treatment $\mathrm{p}$ manure $3 \mathrm{t} / \mathrm{ha}+100 \%$ composite maize recommendation fertilizer: Urea $350 \mathrm{~kg}$ $+100 \mathrm{~kg} \mathrm{SP}-36+\mathrm{KCl} 50 \mathrm{~kg} / \mathrm{ha}$.

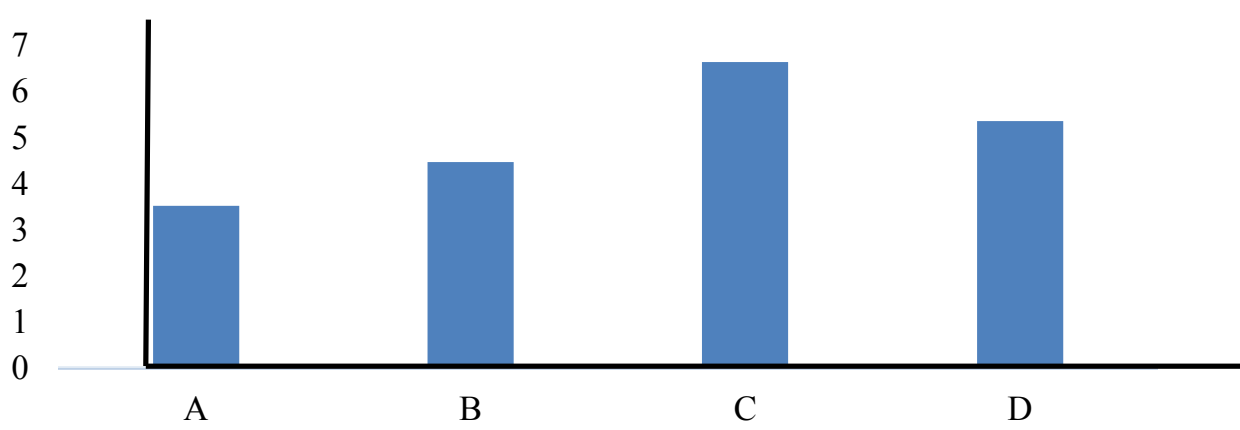

Fig 1. Yield average of maize cultivation.

The yield of lamuru composite in the treatment of manure + inorganic recommended dose of fertilizer was statistically significantly different from the other treatments. The results showed that the combination of manure 3 tons $/$ ha $+50 \%$ recommendation of composite corn fertilizer recommendation: Urea $175 \mathrm{~kg}+50 \mathrm{~kg}+\mathrm{SP}-36+\mathrm{KCl} 25 \mathrm{~kg} / \mathrm{ha}+$ Biosilica bio fertilizer gave the best maize growth and yield, with shelled production. dry corn is $6.2 \mathrm{t} / \mathrm{ha}$ (moisture content $17-18 \%$ ), this result shows that it is $16 \%$ higher than the productivity of Pandeglang Regency in 2019 [17]. But the use of manure $3 \mathrm{t} / \mathrm{ha}+75 \%$ fertilizer recommendation for composite corn: Urea $262.5 \mathrm{~kg}+75 \mathrm{~kg}+\mathrm{SP}-36+\mathrm{KCl} 37.5$ $\mathrm{kg} / \mathrm{ha}+$ Biosinta did not show a significant difference in dry seed yield compared to the treatment of manure $3 \mathrm{t} / \mathrm{ha}+50 \%$ composite maize fertilizer recommendation: Urea $175 \mathrm{~kg}$ $+50 \mathrm{~kg}+\mathrm{SP}-36+\mathrm{KCl} 25 \mathrm{~kg} / \mathrm{ha}+$ Biosinta. This means that the cultivation of composite corn in dryland gives a positive response to corn yields when given a combination of organic fertilizers and biological fertilizers and inorganic fertilizers and there is an efficiency of using inorganic fertilizers as much as $50 \%$. In this experiment, it was shown that the use of biosynta biofertilizer and inorganic NPK fertilizer at a dose of 50\% in dry land had a positive effect on increasing Lamuru composite maize yields and could reduce the dose of inorganic fertilizer recommended by $50 \%$ which means corn farming is more 
efficient. The same result was also reported by Sulaiman et al.[8]. that the use of manure (sluge) accompanied by NPK fertilization on hybrid corn can reduce inorganic fertilizers by $50 \%$. Furthermore, higher maize yields were obtained in the combination treatment between NPK fertilization and organic fertilization compared to only one type of inorganic or organic fertilizer [18]. The results of other studies also show that the application of NPK fertilizers and biological fertilizers in soybean cultivation can provide a positive response to growth and can increase yields and can reduce the use of inorganic fertilizers by $50 \%$ [19].

\subsection{Biomass Performance of Maize Plants}

Maize plants absorb carbon from the soil which is represented by the weight of biomass in each part of the plant [20]. The lowest total weight of maize biomass residue at harvest was achieved if only manure and inorganic fertilizer were applied without Biosinta bio fertilizer. The distribution of Lamuru composite corn biomass on biological fertilizer treatment with $50 \%$ inorganic fertilizer and $75 \%$ recommended dose increased significantly so that the total biomass increased from 2.57 to $4.66 \mathrm{t} / \mathrm{ha}$. In this experiment, the combination of Biosinta bio fertilizer $+50 \%$ inorganic fertilizer and $75 \%$ inorganic dose + biosinta bio fertilizer was not significantly different. Therefore, the treatment of biological fertilizers combined with $50 \%$ inorganic fertilizers is technically better because it can save $50 \%$ of inorganic fertilizers. Application of 50\% NPK fertilizer with the addition of organic fertilizer on ultisol dry land in Lampung can increase corn biomass [21].

Table 2. Biomass performance of maize plants

\begin{tabular}{|c|c|c|c|c|c|c|}
\hline Treatment & $\begin{array}{c}\text { Root } \\
\mathbf{t}^{\text {-ha }}\end{array}$ & $\begin{array}{c}\text { Corn } \\
\text { Stalks t }\end{array}$ & $\begin{array}{c}\text { Corn } \\
\text { leaves } \\
\mathbf{t}^{\text {-ha }}\end{array}$ & $\begin{array}{c}\text { Corncob } \\
\text { without seeds t } \\
\text { ha }\end{array}$ & $\begin{array}{c}\text { Corn } \\
\text { husks } \\
\mathbf{t}^{\text {-ha }}\end{array}$ & $\begin{array}{c}\text { Total of } \\
\text { Biomass t }_{\text {ha }}\end{array}$ \\
\hline $\mathrm{A}$ & $0.55 \mathrm{~b}$ & $0.69 \mathrm{~b}$ & $0.68 \mathrm{~b}$ & $0.45 \mathrm{~b}$ & $0.20 \mathrm{c}$ & $2.57 \mathrm{c}$ \\
\hline $\mathrm{B}$ & $0.59 \mathrm{~b}$ & $0.72 \mathrm{~b}$ & $0.67 \mathrm{~b}$ & $0.67 \mathrm{~b}$ & $0.68 \mathrm{~b}$ & $3.12 \mathrm{~b}$ \\
\hline $\mathrm{C}$ & $0.58 \mathrm{~b}$ & $1.02 \mathrm{a}$ & $0.98 \mathrm{a}$ & $0.98 \mathrm{a}$ & $0.61 \mathrm{~b}$ & $4.66 \mathrm{a}$ \\
\hline $\mathrm{D}$ & $0.72 \mathrm{a}$ & $1.09 \mathrm{a}$ & $1.15 \mathrm{a}$ & $0.89 \mathrm{a}$ & $0.81 \mathrm{a}$ & 4.45 \\
\hline
\end{tabular}

\section{Conclusions}

The combination of organic fertilizer, recommended inorganic fertilizer and Biosinta biological fertilizer gave the best response to the growth and yield of shelled corn in paddy fields. The $\mathrm{C}$ treatment with application of manure $3 \mathrm{t} / \mathrm{ha}+50 \%$ fertilizer recommendation for composite corn: Urea $175 \mathrm{~kg}+50 \mathrm{~kg}+\mathrm{SP}-36+\mathrm{KCl} 25 \mathrm{~kg} / \mathrm{ha}+$ Biosinta gave 6.2 tons/ha of corn husks. This result is $16 \%$ higher when compared to the productivity of Pandeglang Regency in 2019 which reached 5.3 t/ha.

Acknowledgements. We would like to thank the Indonesian Agency for Agricultural Research and Development (IAARD), Indonesian Ministry of Agriculture for the financial support provided for the research. And also our special thanks of gratitude belong to Ir. Resmayeti Purba, M.Si. for guidance and assistance in writing this paper.

\section{Reference}

1. Aldilah, R. Analisis Kebijakan Pertanian. 15, 1:43-62 (2017). 
2. Sulaeman Y., D Nursyamsi, LR Widowati, Husnaen, M Sarwani. Proceedings of the International Workshop on Soil Information System-oriented Nutrient Management for Major Asian Crops. Science City of Munoz, Nueva Ecija, Philippines. (2012)

3. Widodo, KH dan Z. Kusuma. Jurnal Tanah dan Sumberdaya Lahan 5, 2:959-967 (2018)

4. Khair, H., Pasaribu, M. S., Suprapto,. AGRIUM: Jurnal Ilmu Pertanian, 18, 1:13-22 (2013)

5. Sofyan ET and Sara DS. 2018. J Trop Soils, 23,3:111-116 ISSN 0852-257X ; E-ISSN 2086-6682 (2018)

6. Syariffudin. Jurnal Pengkajian dan Pengembangan Teknologi Pertanian 19,2:119-133 (2016).

7. Hanifa H, SNH Utami, C Wulandari, WA Yusuf. 2019. Soil chemical properties and corn productivity as affected by application of different types of fertilizer and planting method in acid sulfate soil. IOP Conf. Series: Earth and Environmental Science 393: 012001 IOP Publishing doi:10.1088/1755-1315/393/1/012001 (2019).

8. Sulaeman, Y., Maswar dan D. Erfandi. Jurnal Pengkajian dan Pengembangan Teknologi Pertanian, 20,1: 1-12. (2017)

9. Moelyohadi, Y., Harun, M.U., Hayati, R., Gofar, H. Journal of Suboptimal Lands, 1,1: 31-39 (2012).

10. Anonim, Indonesian Agricultural Postharvest Research and Development (ICAPOSTRD). Laporan Kinerja Tahun 2019. Sakip.per tanian.go.id/admin/data2/LAKIN\%20BB\%20PASCAPANEN\%202019.pdf (2019).

11. A Asnah, M Masyhuri, JH Mulyo, S Hartono. IOP Conf. Series: Earth and Environmental Science 215: doi :10.1088/1755-1315/215/1/012021 (2021).

12. Yamato M, Okimori Y, Wibowo IF, Anshori S and Ogawa M . J. Soil Sci. Plant Nutr.52 489-495 (2016)

13. Rondon MA, LehmanJ,RamiresJ and Hurtado M. Biol. Fertil. Soils, 43: 699-708 (2007).

14. F Mahmood, I Khan, U Ashraf, T Shahzad, S Hussain, M Shahid, M Abid, S Ullah. Effects of organic and inorganic manures on maize and their residual impact on soil physico-chemical properties. Journal of Soil Science and Plant Nutrition 17,1: 22-32 (2017)

15. J Purwani and Nurjaya. J Trop Soils, 25,1: 11-20 ISSN 0852-257X ; E-ISSN 20866682. DOI: 10.5400/jts.2020.v25i1.11 (2020)

16. Kalay, A.M, R, Hindersah, I.A.Ngabalin, M.Jamlean. Pemanfaatan pupuk hayati dan bahan organik terhadap pertumbuhan dan hasil tanaman jagung. Agric 32, 2:129-138. (2016)

17. BPS-Statistics of Banten Province. Banten Province in Figures 2020. ISBN: 978-6237114-14-7 (2021).

18. Mahood F, I Khan, U Ashraf, T Shahzad, S Hussain, M Shahid, M Abid, S Ullah. J. Soil Sci. Plant Nutr 17,1. http://dx.doi.org/10.4067/S0718-95162017005000002 (2017)

19. Resmayeti, P. Jurnal Pengkajian dan Pengembangan Teknologi Pertanian 19,3:253-261 (2016).

20. Charlotte CD, MA Rahaman, AA Robles-Aguilar, S Latif, K Intani, J Müller, ND. Jablonowski. Agronomy 10, 567; doi:10.3390/agronomy10040567 (2020)

21. Maswar and Y. Soelaeman. AGRIVITA Journal of Agricultural Science 38,2:133-141. Doi: 10.17503/agrivita.v38i2.594 (2016) 